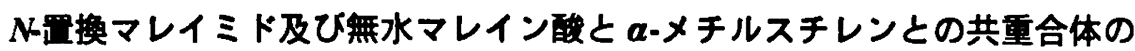 熱分解に及ほすすミド基及ひ酸無水物基の影留
}

\author{
相田 博*1 ・浾崎 美智遠*1 ・前川 浩之*1 ・ 岡崎 正二*1
}

（受付1987年9月5日・䡖奋終了1988年1月29 (1)

\begin{abstract}
要 旨 $N$-エチルマレイミド- $\alpha$-メチルスチレン共重合体 (co-EMI), マレイミド-a-メチルスチレン共重合体

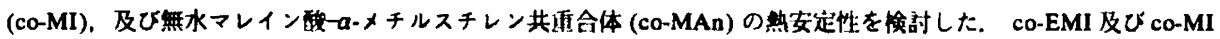

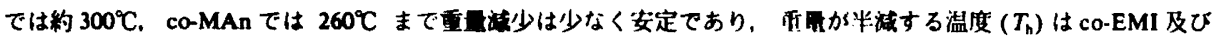

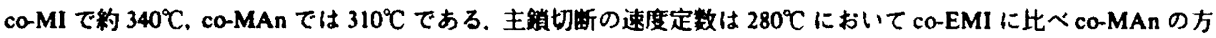

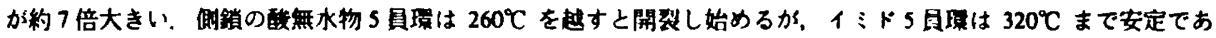

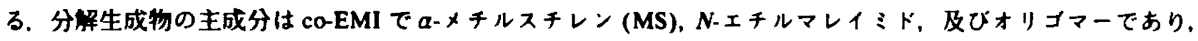

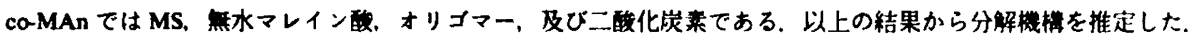

\section{1 粕㝘}

近年, $N$-圆換マレイミドと種々のビニルモ/マーとの 多元共重合体が工業化され市販されている。これら共重 合体は良い酎熱性を示すのみでなく，耐衡盤性などの機 椷的性質, 寸法安定性, 成型性などに優れていることが 多数報告されている゙．しかしなかららこれら共重合体の 熱分解に関する研究は柇熱性高分子として市販されてい ろボリイミド2)に比べ少ないように思われる。

先に我々は無水マレイン酸ースチレン共重合体 (MAnS) $)^{3)}$ 及ひ N-p-置換フェニルマレイミドースチレン共重合 体 (PMI-S) $)^{3)}$ の熟安定性を測定し, 分解の主過程につい て検討した。それによると共重合体は $200^{\circ} \mathrm{C}$ まで安定で あるが，それを越すと初的に主鎖の切断が起こる，特に 前者では主鎖切断によって生じた末端無水マレイン酸ラ シカルからの脱炭酸反応が传先的に起こり，熱安定性は ポリスチレン (PS) に比へ著しく劣ること，後者では前 者より分解温度が高く, p-置换基が電子吸引性であるほ ど主鎖切断がしやすいことを報告した。しかしながら無 水マレイン酸共重合体あるいはマレイミド共重合体の分 解機構についてはこれまで十分な検討がなされていな い.

そこで本報では，N-エチルマレイミドー $a$-メチルスチ レン共重合体 (co-EMI と略す), マレイミト゚ー $a$-メチルス チレン共重合体（co-MI）, 及び無水マレイン酸ー $\alpha$-メチ ルスチレン共重合体 (co-MAn) の熱分解を行い,コモ/ マーの組合せによって生ずる異種モ/マー間の結合の切

*1 福井大学工学部工業化学科（3910 福井市文京 3-9-1）
断のしやすさ、イミド 5 員環と酸無水物 5 員環の安定性 の相连などについて検討を行い，分解機構を明らかにし ようとした.

\section{2 実験}

\section{1 試蒋}

マレイミド (MI) は Tawney ら"の方法によって合成 し、酢酸エチルで再結晶後、昇華 $\left(80^{\circ} \mathrm{C} / 5 \mathrm{mmHg}\right)$ によ り精製した. $N$-エチルマレイミド (EMI) は市販特級品 を昇華 $\left(38^{\circ} \mathrm{C} / 2 \mathrm{mmHg}\right)$ により精製した。無水マレイン 酸は市眅特級品を窒素䒩囲気下，隇圧蒸留により精製し た. $\alpha$ ーメチルスチレン (MS) は市販特級品を $10 \%$ チオ 硫酸ナトリゥム水溶液，水，10\%水酸化ナトリウム水溶 液，水の順で洗浄し，坫化カルシゥムで脱水後，窂菜要 用気下，減压蒸留 $\left(62^{\circ} \mathrm{C} / 23 \mathrm{mmHg}\right)$ により精製した。 へ ンゼン, アソビスインブチロニトリル (AIBN) は常法に

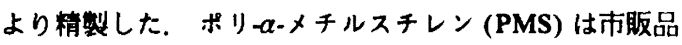
(Aldrich 社)をべンゼンーメチルアルコール系で再沈殿 をくり返し精製した。その他の試薬は市販品（吸光分析 用あるいは特級品）をそのまま使用した。

\section{2 共重合}

マレイミドー $\alpha$-メチルスチレン共重合体 (co-MI) は溶 媒にベンぜンを用いモ/マーを等モル重合管に仕込み， または $N$-エチルマレイミドー $a$-メチルスチレン共重合体 (co-EMI) 及び無水マレイン酸- $\alpha$-メチルスチレン共重合 体 (co-MAn) は溶媒なしでモノマーを等モルずつ重合 管に仕込み，開始郕として AIBN（全モノマー量の0.5 wt\%）を加えて脱気, 塔封後, 温度 $60^{\circ} \mathrm{C}$ で 3 12 時間重 合を行わせて合成した，反応終了後，内容物をエチル 
相田・漆崎・前川・岡崎

Table 1. Properties of various copolymers and poly ( $a$-methylstyrene)

\begin{tabular}{lccc}
\hline Sample & $\begin{array}{c}\text { Conversion } \\
(\%)\end{array}$ & $\begin{array}{c}{[\eta]^{8)}} \\
(\mathrm{d} / / \mathrm{g})\end{array}$ & $\begin{array}{c}\text { Copolymer composition } \\
(\text { mol\%) }\end{array}$ \\
\hline co-EMI & 63.7 & 0.76 & $\begin{array}{c}\text { Ethylmaleimide } \\
51.2\end{array}$ \\
\hline co-MI & 44.0 & 0.16 & $\begin{array}{c}\text { Maleimide } \\
52.6\end{array}$ \\
\hline co-MAn & 41.4 & 0.56 & $\begin{array}{c}\text { Maleic anhydride } \\
49.5\end{array}$ \\
\hline PMS & - & 0.17 & - \\
\hline
\end{tabular}

- Measured in THF (co-EMI and co-MAn), DMF (co-MI), and benzene (PMS) at $30^{\circ} \mathrm{C}$.

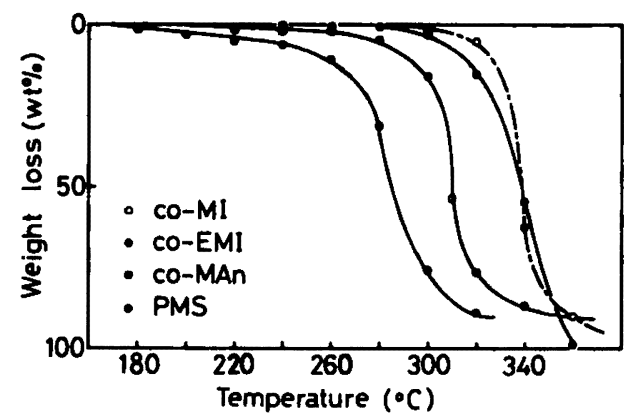

Fig. 1. Weight loss of copolymers and PMS on heating for $1 \mathrm{~h}$ at various temperatures.

エーテルに注いで重合物を沈澱させた。co-EMI 及び co-MAnはアセトンーエチルエーテル系で再沈殿をくり 返して精製した後，アセトンー石油エーテル系で逐次分 別法により 2 区分に分別した。本実糇には 1 区分のみを 使用した。 co-MI は溶媒にエチルエーテルを用いてンッ クスレー抽出器で末反応モノマーなどを抽出し精製し た.

次にゥベローデ希积型粘度計を用い，co-EMI 及び co-MAnでは溶媒にテトラヒドロフランまたは co-MI で は溶媒にジメチルホルムアミドを用い, 温度 $30^{\circ} \mathrm{C} て ゙$ 極 限粘度を測定した。

次に共重合体の組成比は元素分析値（炭素分析値また は窒素分析値) から決定した. 結果を Table 1 に示す.い ずれの試料も共重合体中のマレイミドあるいは無水マレ イン酸の含有量は約 $50 \mathrm{~mol} \%$ であってほぼ 1 対 1 の交 互共重合体であると思われる"

\section{3 装正及ひ方法}

試料約 $100 \mathrm{mg}$ を精秤し赤外用 $\mathrm{KBr}$ 錠剤器でペレット に成形して精枰し，一定温度の熱管炉の中央におき真空 ポンプで脱気後、窒莱で置換し、一定流量 $(50 \mathrm{ml} / \mathrm{min})$
で䆹素を流した。

次に武料 $(500 \mathrm{mg})$ を精秤して反応管に入れ，真空下 $(0.01 \mathrm{mmHg}), 300^{\circ} \mathrm{C}$ 及び $320^{\circ} \mathrm{C}$ で一定時間加熱して発 生する分解生成物を直列に連結したトラップ (室温) 及びトラップ 2 $\left(-78^{\circ} \mathrm{C}\right)$ でそれぞれ捕捉し, 溶液法 (四 塩化炭素) でそれらの赤外線吸収スペクトル（(株)日立 製作所蔽赤外分光光度計 260-30 型）を湘定した。

\section{3 結果及ひ考察}

\section{1 吾減少}

各温度で 1 時間加熱したときの重減少と温度との関 係を Fig. 1 に示す.これから co-MAn は $260^{\circ} \mathrm{C}$, co-EMI 及びco-MI は $300^{\circ} \mathrm{C}$ 以下において重田減少は少なく安 定であるか，その温度を越すとそれぞれ共重合体の重 減少は温度とともに急湤に增加し，100\%近くに達する。

いま，ボリマーの重量加加熱によって $50 \mathrm{wt} \%$ 失われ ろ温度 $\left(T_{h}\right)$ を求めると, co-EMI 及び co-MI では 339 及 び $338^{\circ} \mathrm{C}$, co-MAn では $310^{\circ} \mathrm{C}$, PMS では $287^{\circ} \mathrm{C}$ であり, マレイミド共重合体の $T_{\mathrm{b}}$ は無水マレイン酸共重合体に 比て約 $30^{\circ} \mathrm{C}$ 高い．また対応するスチレン共重合体の $T_{b}$ 値”之比較すると、 $\alpha$-メチルスチレン共重合体の $T_{\mathrm{b}}$ 值は

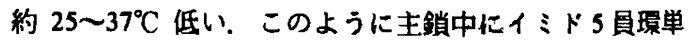
位を望入すると熱安定性は著しく向上するが，側䊑にメ チル基を導入すると熱安定性は低下する。

\section{2 主銧の切断反応}

共重合体は $200^{\circ} \mathrm{C}$ 以上に加熱すると, 加熟残查の粘度 は低下し，主鎖の切断か認められる．粘度の低下は分解 初期で大であり，高温ほどこの㑯向は顯著である.いま， 末分解試料の極限粘度を $[\eta]_{0}$, 加就時間 $九$ 後のそれを $[\eta]$ ，として所定温度で 1 時間加熱したときの $[\eta] /[\eta] 。$ と加熱温度との関係を Fig. 2 に示す。これより co-EMI 及び co-MAn の粘度低下の割合は $240^{\circ} \mathrm{C}$ まで同程度で あるが、この温度を越すと両者の差は大となる．特に co-MAn では $240^{\circ} \mathrm{C}$ を越すと温度とともに粘度低下が著 


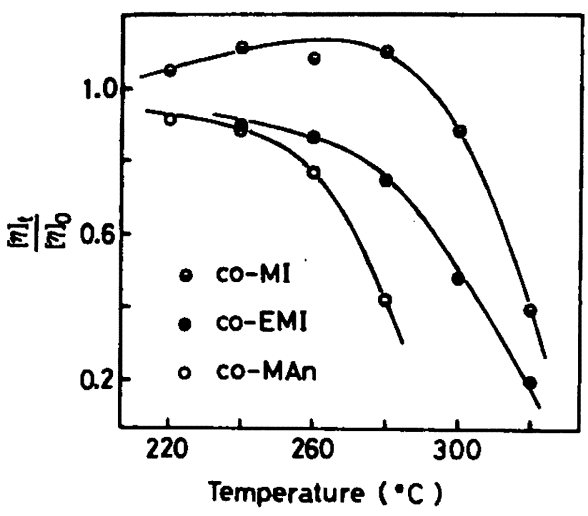

Fig. 2. Changes of $[\eta], / \eta]_{0}$ of residues heated for $1 \mathrm{~h}$ at various temperatures.

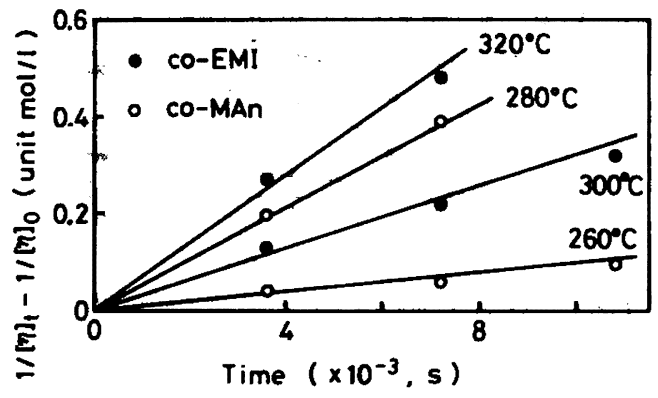

Fig. 3. Relationship between $1 /[\eta],-1 /[\eta]_{0}$ and heating time of copolymers at various temperatures.

しくなり，同じ低下割合を示す温度は co-EMIに比べ約 $20^{\circ} \mathrm{C}$ 低い，一方，co-MI の極限粘度は加熱温度とともに わずかに增大し， $270^{\circ} \mathrm{C}$ て極大を释て著しく減少する。 このことは加熱によって初めに椿かけが起こり，その後 これが再分解するためと思われる。

いま，主鎖切断がランタム分解であると仮定して極限 粘度之重量平均重合度が比例すると次式が得られる。

$$
\frac{1}{[\eta]_{1}}-\frac{1}{[\eta]_{0}}=k^{\prime} t
$$

ここで $k^{\prime}$ は主銷切断の速度定数である。

式 (1)の左辺と時間との関係を Fig. 3 に示す. いずれ の共重合体あ直線夙係を与え式 (1) を満足していると思 われる.この直線の傾きから $k^{\prime}$ を求め, 温度との関係を 示すと Fig. 4 のようになる. いずれの場合す $k^{\prime}$ 值は温 度とともに增大するか，特に co-MAn では $260^{\circ} \mathrm{C}$ を越す と著しく大きくなる. $280^{\circ} \mathrm{C}$ における両者の $\boldsymbol{k}$ 值を比较 すると co-MAn では co-EMI に比へ約 7 倍大きな値を示 す.このように共重合体中に無水マレイン酸単位が導入 されると，主鎖の結合は切断しやすくなる．このことは



Fig. 4. Relationship between rate constants of main chain scission $\left(k^{\prime}\right)$ and heating temperature.

$260^{\circ} \mathrm{C}$ 以上になると熱による主鎖結合の切断に加えて側 銷の酸無水物 5 貝環自身の分解が起こり，これが主鎖切 断反応を促進するためと思われる。

\section{3 加熱残查の IR}

co-MI 及び co-EMI の加熱残查の IR は 320 340 ${ }^{\circ} \mathrm{C}$ ま で元の試料のそれと同じであるが，それ以上ではべンぜ ン㻴に関す万特性吸収帯 $\left(\delta_{\mathrm{CH}}: 701 \mathrm{~cm}^{-1}\right)$ の强度加著し

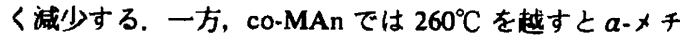
ルスチレン単位に比へ酸無水物 5 貝環に関する特性吸収 帯 ( $\nu_{\mathrm{c} \times 0}: 1861,1781 \mathrm{~cm}^{-1}, \nu_{\mathrm{c}-0 \mathrm{c}}: 1200,1092 \mathrm{~cm}^{-1}$, 骨格振 動: $917 \mathrm{~cm}^{-1}$ ) の強度が隇少し、 $310^{\circ} \mathrm{C}$ に達すると 1706 $\mathrm{cm}^{-1}$ 付近にカルボキシ基, $1760 \mathrm{~cm}^{-1}$ 付近にラクトン懪 に関する新しい吸収帯が生ずる。

そこで種々の温度の加熱残査について溶液法（溶媒： テトラヒドロフラン) でIR を測定して共重合体中のイ ミト5 員桭 $\left(\nu_{\mathrm{c}=\mathrm{o}}: 1689 \mathrm{~cm}^{-1}\right)$ 及び酸無水物 5 員㜊 $\left(\nu_{\mathrm{c}=0}: 1781 \mathrm{~cm}^{-1}\right)$ の熱安定性を調へた。それらの吸光度 と加熱時間との成係を Fig. 5 に示す. co-EMI で吸光度 は $320^{\circ} \mathrm{C}$ までほとんど変化しないが，これ以上の温度に なると時間とともにわずかに增加する傾向にある。 co-MAn では吸光度は $260^{\circ} \mathrm{C}$ までほとんど变化せず一定 であるが、この温度以上になると吸光度は時間とともに 減少し，高温はどこの幁向は著しくなる。

このように酸無水物 5 員環はイミド5員環に比へ熱に よって開裂しやすいと思わ机る。

\section{4 分解生成物}

共重合体は真空中 $(0.01 \mathrm{mmHg})$ で熱分解すると，反 応管壁, トラップ（室温, $-78^{\circ} \mathrm{C}$ 及び $-196^{\circ} \mathrm{C}$ ) に粘着 物，個体，液体、及びガス状物が生成する。これを分離 精㡀し、IR・届折率・融点などを測定した，結果を Table 2 に示す.

共重合体の主な分解生成物は co-EMI では $N$-エチル 


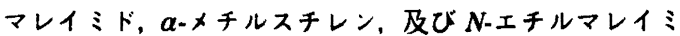
ド単位を多く含有するオリゴマーな゙から成り，これら は全体の約 97 wt\% を占める。なお，co-EMI ではポリー （N-エチルマレイミド）の熱分解6)で生成する $N$-エチル スクシンイミドは確認できなかった。一方, co-MAnで は無水マレイン酸、 $\alpha$-メチルスチレン,オリゴマー, 及 び二酸化炭素から成るが、モノマー類の生成割合は co-EMIに比べ $1 / 2$ 程度である. 他にガス状成分として

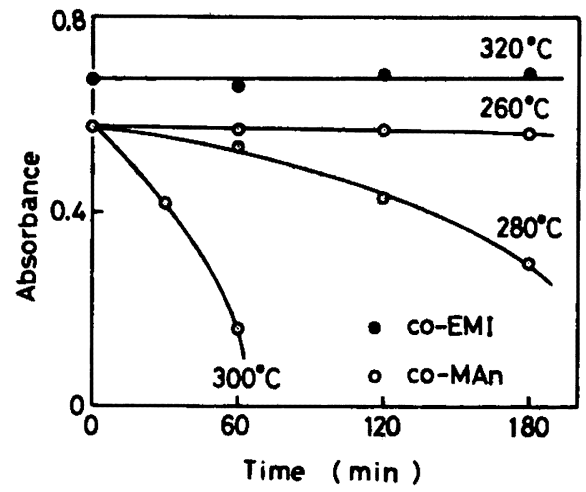

Fig. 5. Dependence of the absorbances of the 1698 $\mathrm{cm}^{-1}$ band characteristic to the maleimide ring in co-EMI and the $1781 \mathrm{~cm}^{-1}$ band characteristic to the acid anhydride ring in co-MAn on the heating time.
二酸化炭素が約 $20 \mathrm{wt} \%$ を占める。オリコマーはカルボ 二ル基 $\left(\nu_{\mathrm{c}=0}: 1706 \mathrm{~cm}^{-1}\right)$, 二重結合 $\left(\nu_{\mathrm{c}=\mathrm{c}}: 1650 \mathrm{~cm}^{-1}\right)$,

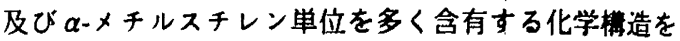
持つ低分子物であり，全体の $50 \mathrm{wt} \%$ を占める。

次に共重合体の主鎖切断のしやすさを調へるため, 主 銷切断後, 逆成辰反応により生成すると予想される $a$-メ チルスチレンの生成量を IR の溶液法（溶媒; 四塩化炭 素）で定量した， 300 及び $320^{\circ} \mathrm{C}$ で熱分解したときの結

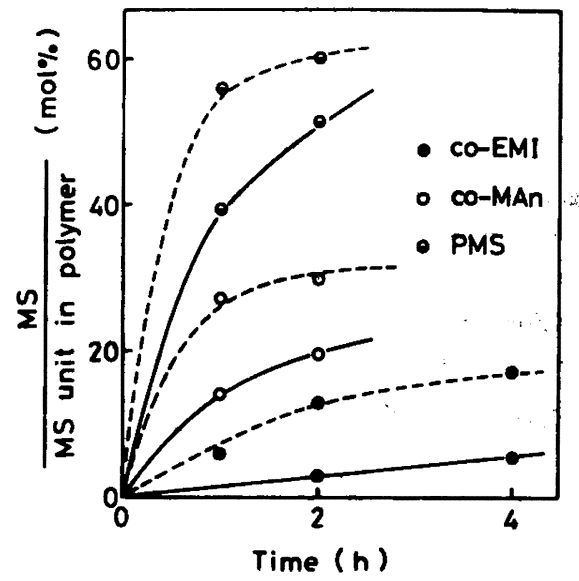

Fig. 6. Dependence of the yield of $\alpha$-methylstyrene on the heating time at $300^{\circ} \mathrm{C}(-)$ and $320^{\circ} \mathrm{C}(-\cdots)$.

Table 2. Pyrolysis products of copolymers and poly ( $\alpha$-methylstyrene) at $300 \sim 320^{\circ} \mathrm{C}^{\text {a) }}$

\begin{tabular}{|c|c|c|c|}
\hline Products & co-EMI & co-MAn & PMS \\
\hline Solid & $\begin{array}{l}21.4 \text { wt\% } \\
N \text {-Ethylmaleimide } \\
\mathrm{mp}, 43 \sim 44.7^{\circ} \mathrm{C} \\
\text { IR, } \nu_{\mathrm{C}=0} 1706 \mathrm{~cm}^{-1} \\
\nu_{\mathrm{C}-\mathrm{N}-\mathrm{C}} 1382 \mathrm{~cm}^{-1}\end{array}$ & $\begin{array}{l}8.6 \text { wt\% } \\
\text { Maleic anhydride } \\
\mathrm{mp}, 52.5 \sim 53.6^{\circ} \mathrm{C} \\
\text { IR, } \nu_{\mathrm{C}=0} 1858,1777 \mathrm{~cm}^{-1}\end{array}$ & \\
\hline Viscous liquid & $\begin{array}{l}42.9 \text { wt } \% \\
\text { Oligomer } \\
\text { IR, } \nu_{\mathrm{c}=\mathrm{O}} 1771,1699 \mathrm{~cm}^{-1} \\
\nu_{\mathrm{C}-\mathrm{N}-\mathrm{C}} 1378 \mathrm{~cm}{ }^{\prime}\end{array}$ & $\begin{array}{l}50.0 \mathrm{wt} \% \\
\text { Oligomer } \\
\text { IR, } \nu_{\mathrm{C}=\mathrm{o}} 1778,1706 \mathrm{~cm}^{-1} \\
\nu_{\mathrm{C}=\mathrm{c}} 1650 \mathrm{~cm}^{-1} \\
\delta_{\mathrm{CH}} 763,700 \mathrm{~cm}^{-1}\end{array}$ & $1.8 w t \%$ \\
\hline Liquid & $\begin{array}{l}32.3 \text { wt\% } \\
a \text {-Methylstyrene } \\
n_{\mathrm{D}}^{25}, 1.5337 \\
\text { IR, } \nu_{\mathrm{C}=\mathrm{c}} 1632 \mathrm{~cm}^{-1} \\
\delta_{\mathrm{CH}} 703 \mathrm{~cm}^{-1}\end{array}$ & $\begin{array}{l}20.3 \text { wt } \% \\
a-\text { Methylstyrene } \\
n_{\mathrm{D}}^{25}, 1.5305 \\
\text { IR, } \nu_{\mathrm{C}=\mathrm{C}} 1629 \mathrm{~cm}^{-1} \\
\delta_{\mathrm{CH}} 708 \mathrm{~cm}^{-1}\end{array}$ & $\begin{array}{l}98.2 \text { wt } \% \\
a \text {-Methylstyrene } \\
\text { IR, } \nu_{\mathrm{c}=\mathrm{c}} 1629 \mathrm{~cm}^{-1}\end{array}$ \\
\hline Gas & $3.4 w t \%$ & $\begin{array}{l}21.1 \mathrm{wt} \% \\
\text { Carbon dioxide } \\
\text { IR, } \nu_{\mathrm{c}=0} 2328 \mathrm{~cm}^{-1} \\
\text { Other }\end{array}$ & \\
\hline
\end{tabular}

\footnotetext{
") Refractive index of $\alpha$-methylstyrene ( $\left.n_{\mathrm{D}}^{25}, 1.5361\right)$.
} 
果を Fig. 6 に示す．なお，比较のため PMS の結果す示 した.ここで縱軸はポリマー中の $\boldsymbol{\alpha}$-メチルスチレン単位

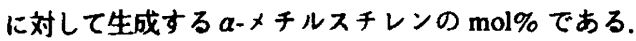

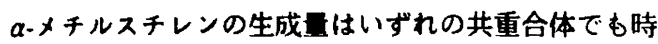
間とともに增加し，高温ほど分解初期で顕著になる。 $300^{\circ} \mathrm{C}$ における生成量を比较すると，co-MAn では co-EMI の約 7 倍多く生成し，高温でもこの㑯向は変わ らない.このようにco-MAn は熱分解によって $\alpha$-メチル スチレンを多く生成し，co-EMI に比へて熱による主鎖 の切断がより多く起こるるのと思われる.

\section{5 分解機㩲}

共重合体は重量減少の少ない分解初期で粘度が低下 し、熱による主銷結合のランダム切断か認められる。こ のことより共重合体の分解の開始はメチル基の立体障 害, 共鳴の大きいフェニル基の寄与、及びカルポニル基 の電子吸引的寄与などにより異種モ/マー間の C-C 結 合（失印のところ）の切断によって起こり、ポリマーラ ジカル (3), (4) を生ずると考えられる. 共重合体の分解

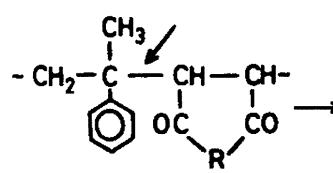

$R: \mathrm{N}-\mathrm{C}_{2} \mathrm{H}_{5}, \mathrm{O}$ (2)

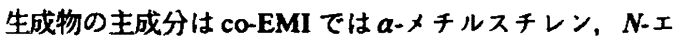

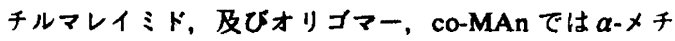
ルスチレン，無水マレイン酸，オリゴマー，及び二酸化 炭素である.このことよりポリマー末端ラジカル(3) は 逆成長反応により $\alpha$-メチルスチレン (5) 及び $N$-エチル

(3)<smiles></smiles>

(5)

(6)

(6)<smiles>CO[Te]1C=C[GeH]1</smiles>

マレイミド(または無水マレイン酸) (7)を脱離する。こ のような反㓪がく返し起こり, 各々モノマーか牲成す ろ. 一方, 末端ラジカル (4)においても同様な逆成長反 応か起こると考えられる。

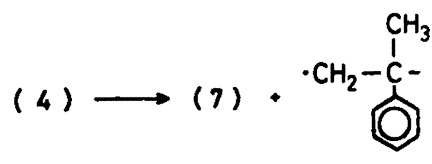

(8)

特に co-MAnでは多量の二酸化炭素が生成する。これ は末端ラジカル (4) あるいは (6) から脱炭酸反応により<smiles>O=C1CC2CC(O1)C(=O)O2</smiles>

(4)

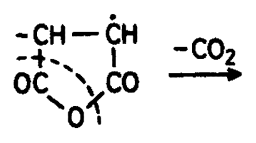

(6)<smiles>CC=C=O</smiles>

(9)

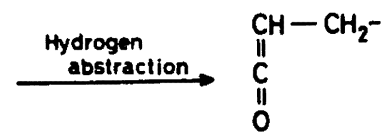

二酸化炭素が生成し，同時にケテン椿造が生じ，ケテン 基は反応性に富むため，反応系外の微晋の水上反応して カルボキシ基になると思われる”，特にco-MAnでは高 温 $\left(260^{\circ} \mathrm{C}\right.$ 以上) になると主鎖切断之同時に側銷の酸無 水物 5 員環自身の分解が起こっていると思われるが，分 解機構については明かでない。

この他に末端ラジカル (4), (6), (8) あるいは (9) は分 子内及び分子間で水素引き抜きを行い，生じた銷上ラシ カルは $\beta$ 切断する. これらの反応がくり返し起こり分子 量が急激に低下して気化できる程度のオリゴマーになる と反応系加失われていくと考えられる。

前述のようにマレイミト 5 員濖と酸無水物 5 員嫄との 間で熱安定性に连いか認められる。これは末端無水マレ イン酸ラシカカルでは脱炭酸反沁が優先して起こるが，末 端イミドラジカルでは前述のような連銷移動反応が生ず るものの, 下式のような共鳴構造の寄与によりラシ்カル

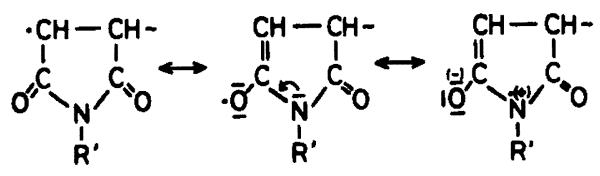

が安定化し，後続の反応が起こりにくくなるためと予想 される.

次に co-MI では分解初期で加熱残查の極限粘度が增 大することから一部橋かけが起こることが示唆され $3^{8}$. これは上述の主鎖からの水素引き抜き反応以外に 决-H からの水素引き抜きが起こり，生じたラジカルが 橋かけ反応に関与すると思われる。 


\section{4 結}

co-EMI，co-MI，及び co-MAn の熱安定性を検討した ところ下記の特徽ある結果か認められた。

1) $T_{\mathrm{b}}$ 值は co-EMI 及び co-MI で約 $340^{\circ} \mathrm{C}$, co-MAn

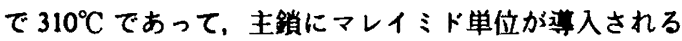
之第安定性は著しく向上する．またこれら共重合体の $T_{\mathrm{h}}$ は対応するスチレン共重合体のそれより約 $25 \sim 37^{\circ} \mathrm{C}$ 低 い.

2) 主銷切断の速度定数（ $k^{\prime}$ 値）は co-MAn では $260^{\circ} \mathrm{C}$ を越えると急粠に增大し， $280^{\circ} \mathrm{C}$ では co-EMIに 比へ約 7 倍大きな值を示す。

3）酸無水物 5 員環は $280^{\circ} \mathrm{C}$ 以上では分解して消失す ろが、イミト 5 員環は $320^{\circ} \mathrm{C}$ まで安定に存在する.

4) 分解生成物の主成分は co-EMI では $N$-エチルマ レイミト、、・メチルスチレン，及びオリゴマーであり， co-MAnでは無水マレイン酸，a-メチルスチレン，オリ

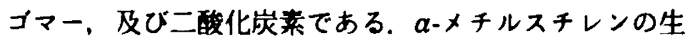

成量はco-MAn の方が約 7 倍多い。

\section{文韵}

1) Chem. Abstr., 106, 214953u (1987); Chem. Abstr., 107, $7821 \mathrm{c}$ (1987); Chem. Abstr., 107, 1549362 (1987); Chem. Abstr., 107, 23905r (1987).

2) T. H. Johnston and C. A. Gaulin, J. Macromol. Sci. Chem., A3, 1161 (1969).

3）潘崎美智遠，松井焦一，坂本正一，相田 博，高分子给文

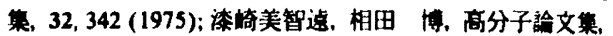
36, 447 (1979).

4) P. O. Tawney, R. H. Snyder, C. E. Bryan, R. P. Conger, F. S. Dovell, R. J. Kelly, and C. H. Stiteler, J. Ong. Chem., 25, 56 (1960).

5) C. C. Price and J. G. Walsh, J. Polym. Sci. 6, 239 (1951).

6) S. Matsui and H. Aida, Polymer, 17, 199 (1976).

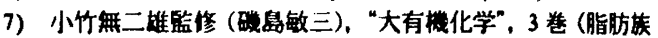
化合物 2)，朝倉息店，東京 (1957).

8）松井韭一，相田 博：高分子化学，28，330 (1971).

Effects of Imide and Acid Anhydride Groups on the Thermal Degradation of N-Substituted Maleimide-a-Methylstyrene and Maleic Anhydride-a-Methylstyrene Copolymers

Hiroshi AIDA*1, Michio UrushizaKI*1, Hiroyuki MaEgawa*1, and Shoji OKazaki*1

*' Faculty of Engineering, Fukui University (3-9-1, Bunkyo, Fukui, 910 Japan)

Thermal degradation of $N$-ethylmaleimide- $\alpha$-methylstyrene (co-EMI), maleimide- $\alpha$-methylstyrene (co-MI), and maleic anhydride- $\alpha$-methylstyrene (co-MAn) copolymers was investigated in a stream of nitrogen ( $50 \mathrm{ml} / \mathrm{min}$ ) or in vacuum over a temperature range of 200 to $360^{\circ} \mathrm{C}$. Co-EMI and co-MI are thermally stable until $300^{\circ} \mathrm{C}$, while co-MAn begins to degrade at a temperature of $260^{\circ} \mathrm{C}$. The temperatures at which weight loss reaches to $50 \mathrm{wt} \%$ on heating the copolymers are $340^{\circ} \mathrm{C}$ for co-EMI and co-MI, and $310^{\circ} \mathrm{C}$ for co-MAn. The rate constant of the main chain scission of co-MAn is about 7 times that of co-EMI. The acid anhydride groups in the copolymer begin to decompose above $260^{\circ} \mathrm{C}$, while imide ring groups are stable until $320^{\circ} \mathrm{C}$. Pyrolysis products of the co-EMI are $a$-methylstyrene (MS), $\boldsymbol{N}$-ethylmaleimide, and oligomers and those of co-MAn are MS, maleic anhydride, oligomers, and carbon dioxide. The degradation mechanism is discussed on the basis of the results obtained.

KEY WORDS Thermal Degradation / N-Substituted Maleimide- $\alpha$-Methylstyrene Copolymer / Maleic Anhydride$a$-Methylstyrene Copolymer / Weight Loss / Main Chain Scission / Pyrolysis Product / N-Ethylmaleimide /

(Received September 5, 1987: Accepted January 29, 1988)

[Kobunshi Ronbunshu, 45(4), 333-338 (1988)] 